\title{
Hubungan Kebersihan diri, Sanitasi, dan Riwayat Penyakit Infeksi Enterik (diare) dengan Kejadian Stunting pada balita usia 24-60 bulan
}

\section{The relationship between personal hygiene, sanitation, and a history of gastrointestinal infections (diarrhea) with the incidence of stunting in infants aged 24-60 months}

\section{Sutarto $^{1}$, Reni Indriyani ${ }^{2}$, Ratna Dewi Puspita Sari ${ }^{3}$, Jeffrey Surya ${ }^{4}$, Rasmi Zakiah Oktarlina ${ }^{5}$}

\author{
${ }^{1,3}$ Bagian Ilmu Kedokteran Komunitas dan Kesehatan Masyarakat, Fakultas \\ Kedokteran, Universitas Lampung \\ ${ }^{2}$ Jurusan Gizi, Poltekkes Tanjungkarang, Bandar Lampung \\ ${ }^{3}$ Bagian Ilmu Kebidanan dan Penyakit Kandungan, Fakultas kedokteran, \\ Universitas Lampung \\ ${ }^{4}$ Fakultas Kedokteran, Universitas Lampung \\ ${ }^{5}$ Program Studi Farmasi, Fakultas Kedokteran, Universitas Lampung
}

Korespondensi penulis: sutarto@fk.unila.ac.id, rasmizakiahoktarlina@gmail.com

Penyerahan: 15-12-2020, Perbaikan: 27-02-2021, Diterima: 30-02-2021

\begin{abstract}
Stunting among children is a chronic impact of long-term low dietary intake accompanied by infectious diseases and environmental issues. Bad hygiene practices and sanitation can lead to enteric infection disease (diarrhea) that can make the children lost some nutrients for body growth. The purpose of this study was to determine the relationship between personal hygiene, sanitation, and a history of enteric infection (diarrhea) with the incidence of stunting in children aged 24-60 months in the Way Urang Community Health Center, South Lampung Regency. This study was an observational analytic study with case-control design. The samples size of this research was 88 toddlers aged 24-60 months which consisted of 44 samples of case group and 44 samples of control group. The dependent variable was stunting status, while the independent variables were kebersihan diri, sanitation, and history of enteric infection (diarrhea). The relations between variables were analyzed using Chi Square with Odd Ratio. Personal hygiene $(p=0.003 ; O R=4.179)$, sanitation $(p=0.019 ; O R=3,095)$, and the history of enteric infection (diarrhea) $(p=0.004$; $O R=4.259$ ) have a significant relation with the stunting incidences. There is a relationship between personal hygiene, sanitation, and a history of diarrhea disease with the incidence of stunting in children aged 24-60 months at the Way Urang Community Health Center, South Lampung Regency.
\end{abstract}

Keywords: toddlers, personal hygiene, history of gastrointestinal infections (diarrhea), sanitation, stunting.

\begin{abstract}
ABSTRAK
Stunting pada anak adalah sebuah dampak kronis dari rendahnya asupan gizi jangka panjang yang dapat disertai dengan penyakit infeksi dan masalah kesehatan lingkungan. Perilaku hygiene dan sanitasi yang kurang baik dapat menyebabkan penyakit infeksi enterik (diare) yang bisa membuat anak-anak kehilangan nutrisi untuk tumbuh kembang. Tujuan penelitian ini menentukan hubungan antara kebersihan diri, sanitasi, dan riwayat penyakit infeksi enterik (diare) dengan kejadian stunting pada balita usia 24-60 bulan di Wilayah Kerja Puskesmas Way Urang Kabupaten Lampung Selatan. Penelitian ini adalah
\end{abstract}

Jurnal Dunia Kesmas, Vol. 10 No. 1, Januari 2021, hal. 56-65

ISSN 2301-6604 (Print), ISSN 2549-3485 (Online)

http://ejurnalmalahayati.ac.id/index.php/duniakesmas/index 
penelitian observasional analitik dengan desain case-control. Jumlah dari sampel dari penelitian ini 88 balita berusia 24-60 bulan yang terdiri dari 44 kelompok kasus dan 44 kelompok kontrol. Variabel terikat dari penelitian ini adalah kejadian stunting dengan variabel bebas kebersihan diri, sanitasi, dan riwayat penyakit infeksi enterik (diare). Hubungan antar variabel dianalisis menggunakan uji Chi Square dengan Odd Ratio. Kebersihan diri $(p=0.003 ; O R=4.179)$, sanitasi $(p=0.019 ; O R=3.095)$, dan riwayat penyakit infeksi enterik (diare) $(p=0.004 ; O R=4.259)$ mempunyai hubungan yang signifikan dengan kejadian stunting. Simpulan bahwa terdapat hubungan antara kebersihan diri, sanitasi, dan riwayat penyakit diare dengan kejadian stunting pada balita usia 24-60 bulan di wilayah kerja Puskesmas Way Urang Kabupaten Lampung Selatan

Kata kunci: balita, kebersihan diri, riwayat penyakit infeksi enterik (diare), sanitasi, stunting.

\section{PENDAHULUAN}

Stunting merupakan suatu
permasalahan kesehatan yang semakin banyak ditemukan di negara berkembang. Menurut UNICEF (2018) ada sekitar 151 juta anak di dunia terutama di negara berkembang yang mengalami stunting (UNICEF, 2018). Kejadian stunting di Indonesia menempati urutan kelima di dunia dan urutan ketiga di Asia Tenggara, 30,8\% (Kemenkes RI, 2019). Provinsi Lampung memiliki prevalensi stunting $27,3 \%$, terdiri dari 9,6\% sangat pendek (severely stunted) dan $17,7 \%$ (stunted) (Badan Penelitian dan Pengembangan Kesehatan, 2018). Kabupaten Lampung Selatan, Lampung Timur, Lampung Tengah, dan Tanggamus termasuk dalam 100 kabupaten/kota dalam prioritas intervensi pemerintah dalam penanganan stunting. Lampung Selatan menempati peringkat ketiga dengan prevalensi stunting 43,01\% sebanyak 42.971 jiwa penderita stunting (Sekretariat Wakil Presiden Republik Indonesia, 2018). Prevalensi stunting di Lampung Selatan 23,3\% tahun 2015 dan mengalami peningkatan tahun 2016 24,8\% dan meningkat lagi menjadi 30,3\% tahun 2017 (Dinas Kesehatan Lampung Selatan, 2017, 2018). Pada tahun 2018, 10 desa di kabupaten Lampung Selatan yang termasuk ke dalam 1.000 desa prioritas tahap 1 (satu) untuk intervensi penangan stunting.
Sepuluh desa tersebut Desa Pancasila, Desa Tajimalela, Desa Taman Agung, Desa Banjarmasin, Desa Bangun Rejo, Desa Kemukus, Desa Batu Balak, Desa Way Gelam, Desa Karya Mulya Sari, dan Desa Mekarsari, (Sekretariat Wakil Presiden RI \& TNP2K, 2017), di antaranya terdapat 2 desa merupakan berada di wilayah kerja Puskesmas Way Urang.

Kementerian Kesehatan Republik Indonesia menjelaskan bahwa terdapat 3 hal yang harus diperhatikan dalam pencegahan stunting yaitu pola makan, pola asuh, serta perbaikan sanitasi dan akses ke air bersih. Hal ini dijelaskan bahwa seringkali masalah non kesehatan menjadi akar masalah dari tingginya stunting terutama di Indonesia (MCA Indonesia, 2013). Kerangka intervensi stunting yang dilakukan oleh Pemerintah Indonesia dibagi menjadi dua yaitu intervensi gizi spesifik dan intervensi gizi sensitif. Intervensi gizi spesifik merupakan intervensi jangka pendek yang ditujukan kepada anak/bayi dalam 1.000 Hari Pertama Kehidupan (HPK) dan intervensi ini berkontribusi sebanyak $30 \%$ untuk menurunkan angka stunting di Indonesia. Intervensi ini terdapat bermacammacam intervensi utama yang dimulai dari masa kehamilan ibu hingga melahirkan balita. Intervensi gizi sensitif melalui berbagai kegiatan 
di luar dari bidang kesehatan dan berkontribusi sebesar $70 \%$ dalam menurunkan angka stunting. Sasaran dari intervensi ini tidak dikhususkan pada ibu hamil dan bayi melainkan masyarakat umum. Kegiatankegiatan dari kerangka intervensi ini adalah menyediakan dan memastikan akses terhadap air bersih, menyediakan dan memastikan akses terhadap sanitasi, melakukan fortifikasi bahan pangan, menyediakan akses kepada layanan masyarakat dan Keluarga Berencana (KB), menyediakan Jaminan Kesehatan Nasional, pendidikan gizi masyarakat, menyediakan bantuan dan jaminan sosial pada keluarga miskin, dan meningkatkan ketahanan pangan dan gizi, dan lain-lain (Sekretariat Wakil Presiden RI \& TNP2K, 2017).

Intervensi gizi saja belum cukup untuk mengatasi masalah stunting. Faktor sanitasi dan kebersihan lingkungan juga berpengaruh terhadap kesehatan ibu hamil dan tumbuh kembang anak, karena anak usia di bawah dua tahun sangat rentan terhadap berbagai penyakit. Paparan terus menerus terhadap kotoran manusia dan hewan dapat meningkatkan risiko infeksi bakteri. Infeksi tersebut disebabkan oleh praktik sanitasi dan kebersihan yang kurang baik sehingga mengakibatkan gizi sulit diserap oleh tubuh. Rendahnya sanitasi dan kebersihan lingkungan juga memicu gangguan saluran pencernaan yang mengakitbatkan energi untuk pertumbuhan teralihkan ke imun tubuh dalam menghadapi penyakit infeksi. Selain itu, selera makan anak akan berkurang ketika sedang sakit sehingga asupan gizi menjadi makin rendah. Hal tersebut mengakibatkan pertumbuhan sel otak yang seharusnya sangat pesat dalam dua tahun pertama kelahiran menjadi terhambat. Dampak dari hal tersebut adalah anak tersebut terancam menderita stunting yang mengakibatkan pertumbuhan mental dan fisiknya terganggu sehingga potensinya tidak dapat berkembang dengan maksimal (MCA Indonesia, 2013).

Program sanitasi total berbasis masyarakat (STBM) yang terdiri dari 5 pilar merupakan salah satu langkah dalam menurunkan angka stunting. Pilar-pilar terebut adalah stop buang air besar sembarangan, cuci tangan pakai sabun, pengelolaan air minum dan makanan, pengelolaan sampah, dan pengelolaan limbah cair. Menurut Kemenkes (2018b), program sanitasi total berbasis masyarakat (STBM) yang terlaksana dengan baik dapat berkontribusi menurunkan penyakit diare $94 \%$ serta berkontribusi menurunkan angka stunting $27 \%$. Program STBM hingga saat ini baru mencapai angka $76,71 \%$ atau hanya sekitar 70 juta rumah tangga yang mendapatkan akses sanitasi yang baik (Prayitno \& Widati, 2017). Sebesar 1.290 dari 2.643 desa atau sekitar $48,81 \%$ dari total desa yang telah melaksanakan program STBM. Sanitasi dasar berupa jamban baru mencapai $64,27 \%$ yang masih jauh dari angka yang diharapkan. Begitu pula dengan perilaku hidup bersih (PHBS) sebesar 59,8\% yang belum mencapai target sebesar $62 \%{ }^{5}$. Puskesmas Way Urang memiliki cakupan 14 desa. Semua desa melaksanakan program STBM tetapi belum ada desa yang terlaksana bebas dari buang air besar sembarangan (ODS=open defecation free) sehingga belum ada desa STBM. Cakuan sanitasi layak berupa jamban pada tingkat kabupaten mencapai angka $85,9 \%$ sedangkan wilayah kerja Puskesmas Way Urang mencapai $80 \%$, masih di bawah angka kabupaten (Dinas Kesehatan Lampung Selatan, 2017, 2018). Kabupaten Lampung Selatan pada 
periode 2015 sd. 2017 memiliki peningkatan yang cukup baik dalam hal STBM yaitu 57,3\% (149 desa), $61,9 \%$ (161 desa), dan 74,2\% (193 desa) dengan persentase ODS 1,5\% (4 desa), 2,3\% (6 desa), dan 2 kecamatan. Perilaku Hidup Bersih Sehat (PHBS) untuk mengukur tingkat hygiene seseorang mencapai angka $71,9 \%$ di Kabupaten Selatan tetapi Puskesmas Way Urang hanya mencapai angka $70 \%$ (Dinas Kesehatan Lampung Selatan, 2017). Penyakit akibat sanitasi yang buruk seperti gangguan saluran pencernaan akan berakibat pada gangguan fungsi energi seharusnya untuk pertumbuhan tetapi beralih fungsi untuk pertahanan menghadapi serangan penyakit infeksi, seperti diare, sehingga pertumbuhan tidak maksimal (stunting). Kasus diare di Provinsi Lampung pada semua kelompok umur tahun 2015 (173.710 kasus) atau sebesar $21,4 \%$ dan menurun pada tahun berikutnya (139.885 kasus) atau sebesar $16,9 \%$. Angka kematian balita usia 1-5 tahun akibat diare pada tahun 2015 dan 2016 sebanyak 3 balita (Dinas Kesehatan Lampung Selatan, 2017). Kasus diare di Kabupaten Lampung Selatan pada semua kelompok umur tahun 2016 (27.650) dan tahun 2017 (28.867 kasus). Puskesmas Way Urang memiliki angka kejadian diare sebesar 1.391 kasus dan yang ditangani ada sebanyak 848 orang $(61 \%)$, angka ini masih tergolong rendah jika dibandingkan dengan angka kejadian diare di tingkat kabupaten 107,7\% (Dinas Kesehatan Lampung Selatan, 2018). Dari uraian di atas, bahwa anak stunting telah terjadi di wilayah kerja Puskesmas Way Urang, yang merupakan 2 desa dari 1.000 desa prioritas intervensi pemerintah, masih tingginya angka kejadian diare dan cakupan sanitasi belum mencapai target, sehingga dapat rumusan masalahnya adalah apakah ada hubungan antara kebersihan diri, sanitasi, dan diare dengan kejadian stunting di Puskesmas Way Urang.

\section{METODE}

Rancangan penelitian yang
digunakan peneliti adalah observasional analitik dengan metode case control. Penelitian ini dilakukan untuk mengetahui hubungan kebersihan diri, sanitasi, dan riwayat penyakit infeksi enterik (diare) dengan kejadian stunting pada balita usia 24-60 bulan di wilayah kerja Puskesmas Way Urang Kabupaten Lampung Selatan. Penelitian ini dilakukan pada bulan JanuariFebruari 2020. Penelitian dilakukan di Puskesmas Way Urang Kabupaten Lampung Selatan. Teknik sampling sesuai dengan kriteria inklusi dan eksklusi dengan menggunakan teknik purposive sampling.

Kriteria inklusi terbagi menjadi 2 kelompok di antaranya kelompok kasus dan kontrol yaitu Ibu dengan balita usia 24-60 bulan yang mengalami stunting, Ibu dengan balita usia 24-60 bulan yang tidak mengalami stunting (masing-masing 44 responden jumlah 88 responden), dan yang telah mengikuti kegiatan posyandu 3 kali berturut-turut. Kriteria eksklusi yaitu balita usia 2460 bulan yang mengalami stunting tetapi disertai dengan penyakit kongenital, genetik, dan infeksi kronis.

Variabel bebas penelitian ini adalah kebersihan diri, sanitasi, dan riwayat penyakit infeksi enterik (diare) dikumpulkan menggunakan kuesioner yang sudah diuji validatas dan reliabitasnya. Variabel terikat (kejadian stunting) merupakan data sekunder dari hasil pengukuran oleh petugas kesehatan setempat, kemudian divalidasi dengan melakukan pengukur kembali balita terpilih menggunakan microtoise. 
Hasil pengukuran, khusus balita stunting dikategorikan menjadi balita sangat pendek (Severly stunted, Zskor dibawah -3) dan balita pendek (stunted Z-skor -2 sd. -3). Hasil penelitian dianalisis secara bivariat menggunakan uji chi-square, kemaknaan statistik didapatkan dengan nilai-p kurang dari 0,05. Penelitian pun telah mendapat persetujuan etik dengan nomor 55/UN26.18/PP.05.02.00/2020.

\section{HASIL}

Berdasarkan tabel 1. karakteristik responden menurut usia didapatkan responden yang paling dominan yaitu usia 24-36 bulan sebanyak 44 orang (50\%).

Tabel 1. Karakteristik responden

\begin{tabular}{|c|c|c|}
\hline Karakteristik & $\begin{array}{c}\text { Frekuensi } \\
\text { (n) }\end{array}$ & $\begin{array}{c}\text { Persentase } \\
(\%)\end{array}$ \\
\hline \multicolumn{3}{|l|}{ Usia (bulan) } \\
\hline $24-36$ & 44 & 50 \\
\hline $37-48$ & 33 & 37,5 \\
\hline $49-60$ & 11 & 12,5 \\
\hline \multicolumn{3}{|l|}{ Jenis Kelamin } \\
\hline Laki-laki & 58 & 65,9 \\
\hline Perempuan & 30 & 34,1 \\
\hline \multicolumn{3}{|l|}{ Kebersihan diri } \\
\hline Kurang baik & 47 & 53,4 \\
\hline Baik & 41 & 46,6 \\
\hline \multicolumn{3}{|l|}{ Sanitasi } \\
\hline Kurang baik & 48 & 54,5 \\
\hline Baik & 40 & 45,5 \\
\hline \multicolumn{3}{|l|}{ Diare } \\
\hline $\mathrm{Ya}$ & 56 & 63,6 \\
\hline Tidak & 32 & 36,4 \\
\hline \multicolumn{3}{|l|}{ Stunting } \\
\hline $\begin{array}{l}\text { Severely } \\
\text { stunted }\end{array}$ & 19 & 43,2 \\
\hline Stunted & 25 & 56,8 \\
\hline
\end{tabular}

Berdasarkan tabel 1 karakteristik responden menurut usia didapatkan responden yang paling dominan yaitu usia 24-36 bulan sebanyak 44 orang (50\%). Riskesdas tahun 2018 menunjukkan persentase stunting tertinggi di Indonesia terjadi pada balita dengan kelompok usia 2436 bulan yaitu sebanyak 13,5\% dengan status gizi sangat pendek (severely stunted) dan 22,1\% dengan status gizi pendek (stunted) (Sutarto et al., 2020). Hasil penelitian ini sesuai dengan teori bahwa stunting adalah kondisi gagalnya pertumbuhan balita akibat kurangnya asupan gizi dalam waktu yang cukup lama, dapat dimulai sejak bayi berada dalam kandungan dan pada masa awal setelah kelahiran bayi. Akan tetapi, kondisi stunting terlihat setelah bayi berusia dua tahun (Balietti \& Datta, 2018).

Karakteristik responden menurut jenis kelamin didapatkan responden yang paling dominan yaitu laki-laki sebanyak 58 orang (65,9\%). Penelitian ini didukung oleh penelitian yang dilakukan oleh Aisah, Ngaisyah, dan Rahmuniyati (2019) yang didapatkan bahwa persentase stunting pada balita laki-laki 
sebanyak 28 balita (56\%) dan balita perempuan sebanyak 17 balita (44\%) (Aisah et al., 2019). Postur tubuh dan luas permukaan tubuh laki-laki lebih besar atau lebih luas dibandingkan dengan perempuan yang menyebabkan laki-laki memerlukan zat gizi lebih banyak dibandingkan dengan perempuan (Julia et al., 2019).

Karakteristik responden menurut kebersihan diri didapatkan responden yang paling dominan yaitu Ibu dengan kebersihan diri yang kurang baik sebanyak 47 orang $(53,4 \%)$. Karakteristik responden menurut sanitasi didapatkan responden yang paling dominan yaitu balita yang bertempat tinggal di rumah dengan sanitasi yang kurang baik sebanyak 48 orang $(54,5 \%)$.
Karakteristik responden menurut kejadian diare didapatkan responden yang paling dominan yaitu balita dengan riwayat diare sebanyak 56 orang $(63,6 \%)$.

\section{Karakteristik}

menurut kejadian stunting didapatkan responden yang paling dominan yaitu stunted sebanyak 25 orang $(56,8 \%)$. Hal in sesuai dengan gambaran prevalensi di Indonesia dengan jumlah balita stunting sebesar $30,8 \%$ dengan balita sangat pendek (severely stunted) sebesar $11,5 \%$ dan pendek (stunted) sebesar 19,3 . Provinsi Lampung memiliki prevalensi stunting sebesar $27,3 \%$ yang terdiri dari $9,6 \%$ sangat pendek (severely stunted) dan 17,7\% (stunted) (Aridiyah, F.O., Rohmawati, N., dan Ririanty, 2015).

Tabel 2. Hubungan Kebersihan diri, Sanitasi, dan Riwayat Penyakit Diare dengan Kejadian Stunting pada Balita Usia 24-60 Bulan di Wilayah Kerja Puskesmas Way Urang Kabupaten Lampung Selatan

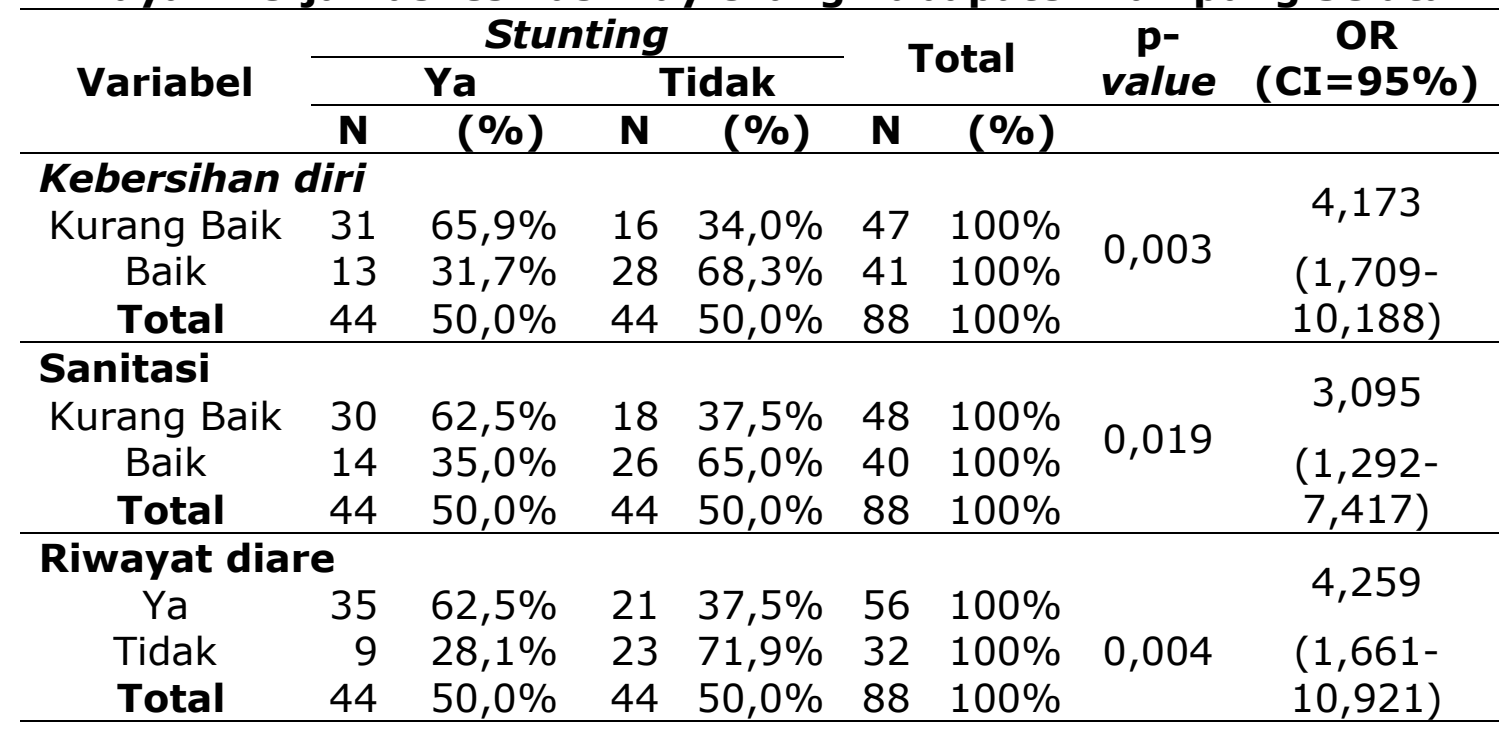

Uji analisis bivariat dilakukan dengan menggunakan uji chi square antara beberapa faktor dengan kejadian stunting. Pada analisis bivariat antara faktor kebersihan diri dengan kejadian stunting didapatkan bahwa balita yang mengalami stunting paling banyak $(65,9 \%)$ memiliki Ibu dengan kebersihan diri yang kurang baik. Sebaliknya balita yang tidak mengalami stunting paling banyak $(68,3 \%)$ memiliki Ibu dengan kebersihan diri yang baik. Nilai $p$ yang didapatkan adalah 0,003 (nilai $p$ $<0,05$ ) sehingga didapatkan hasil terdapat hubungan antara kebersihan diri dengan kejadian stunting pada balita usia 24-60 bulan di wilayah kerja Puskesmas Way Urang Kabupaten Lampung Selatan. 
Pada analisis bivariat antara faktor sanitasi dengan kejadian stunting didapatkan bahwa balita yang mengalami stunting paling banyak $(62,5 \%)$ memiliki tempat tinggal dengan sanitasi yang kurang baik, sebaliknya balita yang tidak mengalami stunting paling banyak $(65,0 \%)$ memiliki tempat tinggal dengan sanitasi yang baik. Nilai $p$ yang didapatkan adalah 0,019 (nilai $p$ $<0,05$ ) sehingga didapatkan hasil terdapat hubungan antara sanitasi dengan kejadian stunting pada balita usia 24-60 bulan di wilayah kerja Puskesmas Way Urang Kabupaten Lampung Selatan.

Pada analisis bivariat antara faktor riwayat penyakit diare dengan kejadian stunting didapatkan bahwa balita yang mengalami stunting paling banyak $(62,5 \%)$ memiliki riwayat penyakit diare, sebaliknya balita yang tidak mengalami stunting paling banyak $(71,9 \%)$ tidak memiliki riwayat diare. Nilai $p$ yang didapatkan adalah 0,004 (nilai $p<0,05$ ) sehingga didapatkan hasil terdapat hubungan antara riwayat diare dengan kejadian stunting pada balita usia 24-60 bulan di wilayah kerja Puskesmas Way Urang Kabupaten Lampung Selatan.

\section{PEMBAHASAN}

Analisis hubungan antara kebersihan diri dengan kejadian stunting menunjukkan bahwa ada hubungan antara kebersihan diri dengan kejadian stunting pada balita usia 24-60 bulan di wilayah kerja Puskesmas Way Urang Kabupaten Lampung Selatan. Hasil penelitian ini sebanding dengan penelitian yang dilakukan oleh Sinatyra dan Muniroh (2019), bahwa hubungan antara kebersihan diri dengan kejadian stunting secara statistic bermakna ${ }^{16}$. Cuci tangan merupakan teknik dasar yang paling penting dalam pencegahan penyakit infeksi. Kebiasaan cuci tangan menggunakan sabun tidak hanya mengurangi melainkan juga mencegah penyakit diare dan ISPA pada anak, selanjutnya penyakit diare dan ISPA ini, pada anak/bayi dapat mengakibatkan anak menjadi stunting karena tumbuh kembang anak terganggu (Herawati et al., 2020). Demikain pula, penelitian oleh Aisyah bahwa hubungan yang signifikan antara personal hygiene dengan kejadian stunting, dengan nilai Odds Ratio (OR) sebesar 0,116 dan bersifat berprotektif, artinya bila personil hgiene dirutin dilakukan maka akan mencegah kajadian stunting (Aisah et al., 2019).

Pengasuh balita yang
mempunyai perilaku praktik higiene yang kurang baik, akan mempunyai dampak pada asupan makanan yang dikonsumsi oleh balita. Balita yang mengonsumsi makanan karena perilaku praktik higiene yang kurang baik dapat meningkatkan risiko anak tersebut terkena penyakit infeksi, biasanya ditandai dengan adanya gangguan nafsu makan, muntahmuntah, ataupun diare sehingga asupan gizi balita tersebut kurang memenuhi kebutuhannya dan kondisi ini dapat berimplikasi buruk pada pertumbuhan anak. Pengasuh balita dan balita yang mempunyai kebiasaan perilaku praktik higiene yang baik, seperti mencuci tangan menggunakan sabun setelah melakukan BAB (Buang Air Besar) dan sebelum makan, dapat menurunkan risiko balita terkena stunting sebesar $14 \%$ dan jika mencuci tangan menggunakan sabun sebelum makan anak menurunkan risiko stunting sebanyak $15 \%$. Perilaku higiene yang baik yang dilakukan ibu atau pengasuh balita dapat memberikan efek protektif terhadap kejadian stunting (Aisah et al., 2019).

Analisis hubungan antara sanitasi dengan kejadian stunting 
menunjukkan bahwa ada hubungan antara sanitasi dengan kejadian stunting pada balita usia 24-60 bulan di wilayah kerja Puskesmas Way Urang Kabupaten Lampung Selatan. Hasil penelitian ini sebanding dengan penelitian yang dilakukan oleh Ramdaniati dan Nastiti (2019), dimana diteliti hubungan antara sanitasi dengan kejadian stunting dan didapatkan hubungan yang bermakna (Ramdianiati \& Nastiti, 2019). Sanitasi dan kebersihan lingkungan juga berpengaruh terhadap kesehatan ibu hamil dan tumbuh kembang anak karena anak usia di bawah dua tahun sangat rentan terhadap berbagai penyakit. Rendahnya sanitasi dan kebersihan lingkungan juga memicu gangguan saluran pencernaan yang mengakibatkan energi untuk pertumbuhan teralihkan ke imun tubuh dalam menghadapi infeksi. Dampak dari hal tersebut adalah anak-anak terancam menderita stunting yang mengakibatkan pertumbuhan mental dan fisiknya terganggu sehingga potensinya tidak dapat berkembang dengan maksimal (Yadika et al., 2019).

Keberadaan jamban yang tidak memenuhi syarat kesehatan berpotensi memicu timbulnya beberapa penyakit infeksi (misalnya diare dan kecacingan), sehingga yang dapat menganggu penyerapan nutrisi pada proses pencernaan. Beberapa penyakit infeksi yang diderita anak dapat menyebabkan berat badan bayi turun. Bila kondisi ini terjadi dalam waktu yang lama dapat dapat mengakibatkan anak menjadi stunting (Zairinayati \& Purnama, 2019).

Analisis hubungan antara riwayat penyakit dengan kejadian stunting menunjukkan bahwa ada hubungan antara riwayat penyakit diare dengan kejadian stunting pada balita usia 2460 bulan di wilayah kerja Puskesmas
Way Urang Kabupaten Lampung Selatan (Rahayu et al., 2018; Sutarto \& Bustami, 2017; Sutarto \& Indriyani, 2018). Hubungan antara status gizi anak dan penyakit infeksi adalah hubungan dua arah yaitu penyakit yang sering dapat mengganggu status gizi dan status gizi yang buruk dapat meningkatkan risiko infeksi. Pada penelitian menunjukkan bahwa efek merugikan dari infeksi tertentu (misalnya diare) pada pertumbuhan dapat dikurangi atau dihilangkan dengan memperbaiki gizi sehingga dapat meningkatkan pertumbuhan anak contohnya pada kasus balita yang mengalami stunting dan wasting (Onis et al., 2013; Sutarto et al., 2018). Diare yang terjadi dalam periode yang panjang pada balita berusia dua tahun pertama kehidupan dapat mempengaruhi kejadian retardasi tumbuh kembang. Anak yang terkena diare akan mengalami malabsorbsi zat gizi dan durasi diare yang berlangsung lama (lebih dari 4 hari) sehingga anak mengalami kehilangan zat gizi, bila tidak segera intervensi dan diimbangi dengan asupan yang sesuai makan maka akan terjadi gagal tumbuh (Zairinayati \& Purnama, 2019).

\section{KESIMPULAN}

Terdapat hubungan antara kebersihan diri, sanitasi, dan riwayat penyakit diare dengan kejadian stunting pada balita usia 24-60 bulan di wilayah kerja Puskesmas Way Urang Kabupaten Lampung Selatan.

\section{SARAN}

Kebersihan diri dapat dilaksanakan dengan baik, salah satunya caranya dengan membuat kebijakan daerah agar setiap sekolah membuat kurikulum wajib dan menerapkan di lingkungan sekolah.

Pembekalan pada setiap rumah tangga oleh petugas kesehatan 
setempat tentang penanangan diare di tingkat rumah tangga.

\section{DAFTAR PUSTAKA}

Aisah, S., Ngaisyah, R. D., \& Rahmuniyati, M. E. (2019). Personal Hygiene dan Sanitasi Lingkungan Berhubungan Dengan Kejadian Stunting Di Desa Wukirsari Kecamatan Cangkringan. Prosiding Seminar Nasional Multidisiplin IImu, 1(2), 49-55.

Aridiyah, F.O., Rohmawati, N., dan Ririanty, M. (2015). Faktor-Faktor Yang Mempengaruhi Kejadian Stunting Pada Anak Balita di Wilayah Pedesaan Dan Perkotaan. E-Jurnal Pustaka Kesehatan, 3(1), 163-170. https://doi.org/10.1007/s11746013-2339-4

Badan Penelitian dan Pengembangan Kesehatan. (2018). Hasil Utama Riset Kesehatan Dasar 2018. In Kementrian Kesehatan Republik Indonesia (Vol. 1, Issue 1). https://doi.org/1 Desember 2013

Balietti, A., \& Datta, S. (2018). Growth Lost To Smoke: Household Air Pollution, Stunting, and Wasting Of Children In India Solid Fuels And Household Air Pollution (HAP). June, 1-22.

Dinas Kesehatan Lampung Selatan. (2017). Profil Kesehatan Kabupaten Lampung Selatan Tahun 2016. Dinas Kesehatan Lampung Selatan.

Dinas Kesehatan Lampung Selatan. (2018). Profil Kesehatan Kabupaten Lampung Selatan Tahun 2017 (Taufiqurrosyad (ed.); 1st ed., Issue 06). Dinas Kesehatan Lampung Selatan.

Herawati, H., Anwar, A., \& Setyowati, D. L. (2020). Hubungan Sarana Sanitasi, Perilaku Penghuni, Dan Kebiasaan Cuci Tangan Pakai Sabun (Ctps) Oleh Ibu Dengan Kejadian Pendek (Stunting) Pada
Batita Usia 6-24 Bulan Di Wilayah Kerja Puskesmas Harapan Baru, Samarinda. Jurnal Kesehatan Lingkungan Indonesia, 19(1), 7. https://doi.org/10.14710/jkli.19. 1.7-15

Julia, R., Simanjuntak, D., \& Kurniawaty, E. (2019). Efek Antibakteri Kopi Robusta Yang Difermentasi Dengan Kombucha Terhadap Salmonella Typhi. Jurnal Agroindustri Halal ISSN, 6(1), 754-759.

Kemenkes RI. (2019). Profil Kesehatan Indonesia 2018. Kementerian Kesehatan RI.

MCA Indonesia. (2013). Stunting dan masa depan Indonesia. Millennium Challenge Account - Indonesia, 2010, 2-5.

Onis, M. De, Dewey, K. G., Borghi, E., Onyango, A. W., Blössner, M., Daelmans, B., Piwoz, E., \& Branca, F. (2013). The World Health Organization's Global Target For Reducing Childhood Stunting By 2025: Rationale And Proposed Actions. Maternal \& Child Nutrition, 9(2), 6-26. https://doi.org/10.1111/mcn.120 75

Prayitno, J., \& Widati, S. (2017). Kajian Strategi Promosi Kesehatan Sanitasi Total Berbasis Masyarakat (Stbm) Di Kelurahan Kejawan Putih Tambak Kota Surabaya. Jurnal. Lingkungan, 5(2), 267-274.

Rahayu, R. M., Pamungkasari, E. P., \& Wekadigunawan, C. (2018). The Biopsychosocial Determinants of Stunting And Wasting In Children Aged 12-48 Months. Journal of Maternal And Child Health, 03(02), 105-118. https://doi.org/10.26911/thejmc h.2018.03.02.03

Ramdianiati, siti nur, \& Nastiti, D. (2019). Hubungan Kearakteristik Balita, Pengetahuan Ibu Dan Sanitasi Terhadap Kejadian 
Stunting Pada Balita Di Kecamatan Labuan Kabupaten Pandeglang. Kesehatan Masyarakat, 7(2), 4754.

Sekretariat Wakil Presiden Republik Indonesia. (2018). Strategi Nasional Percepatan Pencegahan Stunting Periode 2018-2024 (Pertama).

Sekretariat Wakil Presiden RI, \& TNP2K. (2017). 100 Kabupaten/Kota Prioritas Untuk Intervensi Anak Kerdil (Stunting). In Tim Nasional Percepatan Penanggulangan Kemiskinan (Ed.), Tim Nasional Percepatan Penanggulangan Kemiskinan (PERTAMA, VOL. 2). Tim Nasional Percepatan Penanggulangan Kemiskinan.

Sutarto, \& Bustami, E. C. (2017). Faktor Lingkungan, Perilaku Dan Penyakit Malaria Environmental Factors, Behavior And Malaria Disease. Jurnal Agromedicine, 4(1), 173-184.

Sutarto, \& Indriyani, R. (2018). Stunting And Poverty. The 3rd Shield International Conference of
2018, 260-263.

Sutarto, Mayasari, D., \& Indriyan, R. (2018). Stunting, Faktor Resiko Dan Pencegahannya. J Agromedicine 1, 5(1), 540-545.

Sutarto, Miswar, D., Sari, R. D. P., Indriyani, R., \& Wibowo, A. (2020). Ecological Study Of Genesis Of Spatial Analysis-Based Stunting. International Journal of Innovation, Creativity And Change, 13(Special), 731-746.

UNICEF. (2018). The Scaling Up Nutrition (Sun) Movement Annual Progress Report 2018. In Annual Progress Report 2018. Phoenix Design Aid.

Yadika, A. D. N., Berawi, K. N., \& Nasution, S. H. (2019). PENGARUH STUNTING TERHADAP PERKEMBANGAN KOGNITIF DAN PRESTASI Belajar. Jurnal Majority, 8(2), 273-282.

Zairinayati, \& Purnama, R. (2019). Hubungan Hygiene Dan Sanitasi Lingkungan Dengan Kejadian Stunting Pada Balita. Jurnal IImiah Multi Science Kesehatan, 10(1), 78-91. 